\title{
PEMBERIAN JUS TOMAT TERHADAP KADAR HEMOGLOBIN PADA IBU HAMIL TRIMESTER III TAHUN 2019
}

\author{
Fitriani ${ }^{1}$, Yulistiana Evayanti ${ }^{2}$, Nurul Isnaini ${ }^{3}$ \\ 1Program Studi DIV Kebidanan Fakultas kedokteran Universitas Malahayati Bandar Lampung \\ Korespondensi Email : fitrianiwn05@gmail.com \\ 2Dosen Universitas Malahayati Bandar Lampung \\ Email : yulistianaevayanti@gmail.com \\ ${ }^{3}$ Dosen Universitas Malahayati Bandar Lampung \\ Email:isnaininurul50@yahoo.co.id
}

\begin{abstract}
Background: Hemoglobin is a dye found in red blood cells and is useful for transporting oxygen and carbon dioxide in the body, hemoglobin is a bond of proteins, iron salts, dyes. During pregnancy, anemia can be prevented and treated using iron and folic acid supplements. Vitamin $C$ is a good combination to help the absorption of iron. One of the fruits that contain vitamin $C$ and compounds useful for health is tomatoes. The content of tomatoes in 180 grams is $24.6 \mathrm{mg}$ of vitamin, $0.49 \mathrm{mg}$ of iron, and $27 \mathrm{mcg}$ of folic acid. Based on preliminary surveys conducted by researchers in January 2019 from the results of observations in the ANC book, it is known that 48 pregnant women including 22 TM III.

Purpose: This study is known the Effect of Tomato Juice Giving on Increased Hemoglobin Levels in Third trimester pregnant women at BPS Rohanah, STr.Keb.

Methods : This type of research is a pre-experimental action study with the design of One group pretest - posttest design. The population in this study were all pregnant women who experienced anemia in trimester III as many as 22 respondents. A sample of 15 people, the sampling technique used was purposive sampling. Data collection using observation sheets and data analysis used is a T-dependent test.

Results : The study revealed the average value of hemoglobin levels before administration of tomato juice 9.687 and standard deviation .4838. The average value of hemoglobin levels after administration of tomato juice 11.773 and standard deviation of 1.0074. There is the influence of tomato juice on increasing HB levels in pregnant women ( $p$ value $0,000<0,05$ ).

Conclusoin: There is an effect of giving tomato juice to increasing $\mathrm{Hb}$ levels in pregnant women. For pregnant women can consume tomato juice on a regular basis to prevent the occurrence of anemia and plenty of adequate rest breaks.

Suggestion: Pregnant women can consume tomato juice regularly to prevent anemia and get plenty of adequate rest.
\end{abstract}

Keywords: tomato juice, haemoglobin level

\section{ABSTRAK}

Latar Belakang :Hemoglobin merupakan zat warna yang terdapat dalam sel darah merah dan berguna untuk mengangkut oksigen dan karbon dioksida dalam tubuh, hemoglobin adalah ikatan protein, garam besi, zat warna. Saat kehamilan, anemia dapat di cegah dan di obati dengan menggunakan zat besi dan suplemen asam folat. Vitamin $\mathrm{C}$ salah satu kombinasi yang baik untuk membantu penyerapan zat besi. Salah satu buah yang mengandung vitamin $C$ dan senyawa bermanfaat untuk kesehatan yaitu tomat. Kandungan tomat dalam 180 gram adalah 24,6 mg vitamin, 0,49 mg zat besi, dan $27 \mathrm{mcg}$ asam folat. Berdasarkan survey pendahuluan yang peneliti lakukan pada januari Tahun 2019 dari hasil observasi pada buku ANC diketahui 48 ibu hamil diantaranya 22 TM III.

Tujuan : Mengetahui Pengaruh Pemberian Jus Tomat terhadap Peningkatan Kadar Hemoglobin pada ibu hamil trimester III di BPS Rohanah, STr.Keb.

Metode : Jenis penelitian ini merupakan penelitian tindakan pra eksperimen dengan rancangan One group pretest - posttest design. Populasi dalam penelitian ini adalah seluruh ibu hamil yang mengalami anemia trimester III sebanyak 22 responden. Sampel 15 orang, Teknik sampling yang digunakan purposive sampling. 
Pengumpulan data dengan menggunakan lembar observasi dan analisa data yang digunakan adalah uji $T$ dependent.

Hasil : Rata-rata kadar hemoglobin sebelum pemberian jus tomat 9.687 dan standar deviasi 4838. Nilai rata-rata kadar hemoglobin sesudah pemberian jus tomat 11.773 dan standar deviasi 1.0074. Ada pengaruh pemberian jus tomat terhadap peningkatan kadar hb pada ibu hamil ( $p$ value $0,000<0,05$ ).

Kesimpulan : Ada pengaruh pemberian jus tomat terhadap peningkatan kadar $\mathrm{Hb}$ pada ibu hamil. Bagi ibu hamil dapat mengkonsumsi jus tomat secara rutin guna pencegahan terjadinya anemia serta banyak istirahat istirahat yang cukup.

Saran: Bagi ibu hamil dapat mengkonsumsi jus tomat secara rutin guna pencegahan terjadinya anemia serta banyak istirahat istirahat yang cukup.

Kata Kunci : Jus tomat, kadar haemoglobin

\section{PENDAHULUAN}

Menurut WHO (2008), prevalensi anemia pada ibu hamil diperkirakan di Asia sebesar 48,2 \%, Afrika 57,1\%, Amerika 24,1\%, dan Eropa 25,1\%. Berdasarkan riskesdas 2013 terdapat 37,1\% ibu hamil anemia, yaitu ibu hamil dengan kadar $\mathrm{Hb}$ kurang dari 11,0 gram/dl, dengan proporsi yang hampir sama antara di kawasan perkotaan $(36,4 \%)$ dan pedesaan $(37,8 \%)$. Meskipun pemerintah sudah melakukan program penanggulangan anemia pada ibu hamil yaitu dengan memberikan 90 tablet Fe kepada ibu hamil selama periode kehamilan dengan tujuan menurunkan angka anemia ibu hamil, tetapi kejadian anemia masih tinggi. (Kementerian Kesehatan RI, 2013)

Berdasarkan data WHO 2015 Anemia merupakan salah satu faktor penyebab tidak langsung kematian ibu hamil. Berdasarkan WHO Prevalensi anemia ibu hamil di dunia berkisar ratarata $14 \%$, di negara industri $56 \%$ dan di negara berkembang antara 35\%-75\%. secara gelobal, sebesar $52 \%$ wanita hamil di negara-negara berkembang mengalami anemia. Angka ini lebih besar di bandingkan dengan angka anemia pada wanita hamil di negara-negara industri yang hanya sebesar 20\%. Negara dengan prevalensi anemia pada wanita hamil tertinggi adalah india ( $88 \%$ ), di ikuti oleh afrika $(50 \%)$, dan karibia (30\%). Berdasarkan WHO tahun 2008 prevalensi anemia ibu hamil di asia tenggara 48,2\%. Menurut encyclopedis of national indonesia berada $\mathrm{di}$ peringkat ke-58 dengan prevalensi anemia pada ibu hamil sebanyak 44,3\%. (WHO, 2015)

Berdasarkan data Riskesdas 2018, angka anemia ibu hamil sebanyak 48,9\%, anemia berdasarkan umur 15-24 tahun sebanyak $84,6 \%$, 25-34 tahun sebanyak 33,7\%, 35-44 tahun sebanyak $33,6 \%$ dan umur $45-55$ tahun sebanyak $24 \%$. Sedangkan ibu hamil yang mendapat tablet tambah darah sebesar $73,2 \%$ dan yang tidak mendapatkan tablet tambah darah sebesar $26,8 \%$. (Kementerian Kesehatan RI, 2018)

Berdasarkan Profil Kesehatan Kota Bandar Lampung tahun 2017 menunjukan data bahwa dari 24733 ibu hamil yang terdapat di kota Bandar Lampung sebanyak 21771 (88\%) mendapat $\mathrm{Fe} 1$ dan $21259(85,9 \%)$ mendapat $\mathrm{Fe} 3$ dan jumlah ibu hamil yang diperiksa $\mathrm{Hb}$ berjumlah 23160 jiwa atau sekitar $93 \%$. Ibu hamil yang mengalami anemia berjumlah $8435(36,4 \%)$ dengan kadar $\mathrm{Hb}$ 8-11 gr/dl dan 810 ibu hamil atau (3,4\%) dengan kadar $\mathrm{Hb}<8 \mathrm{gr} / \mathrm{dl}$. (Dinas Kesehatan Kota Bandar Lampung, 2017).

Faktor kematian maternal dapat di tinjau dari usia dan paritas. Kematian ibu dapat dikarenakan karena hemoragi, 15\% karena sepsis, $12 \%$ karena gangguan hipertensi kehamilan, $8 \%$ karena persalinan macet, dan hamper $13 \%$ karena abortus. Sekitar $20 \%$ wanita meninggal akibat suatu penyakit yang diperberat dengan kehamilan seperti anemia, hioertensi, hepatitis TBC dan penyakit jantung (Kusmiran, 2012).

Dalam kehamilan, jumlah darah bertambah (hyperemia/hipervolumia) karena itu terjadi pengenceran darah karena sel-sel darah tidak sebanding pertambahannya dengan plasma darah. Secara fisiologis, pengenceran darah ini adalah untuk membantu meringankan kerja jantung. (Ani, 2013)

Anemia pada kehamilan adalah anemia karena kekurangan zat besi, dan memrupakan jenis anemia yang pengobatannya realtif mudah, bahkan murah. Anemia pada kehamilan merupakan masalah nasional karena mencerminkan nilai kesejahteraan sosial ekonomi masyarakat, dan pengaruhnya sangat kasar terhadap kualitas sumber daya manusia. (Manuaba, 2010).

Provinsi Lampung tercatat sebagai peringkat utama di wilayah Sumatra untuk jumlah penderita anemia. Tingginya jumlah anemia ibu hamil di provinsi lampung yaitu sebanyak 69,7\% 
angka itu lebih tinggi dari angka anemia gizi nasional yaitu sebanyak 63\% (Dinas Kesehatan Provinsi Lampung, 2010) Anemia adalah suatu kondisi medis dimana jumlah sel darah merah atau hemoglobin kurang dari normal. Kadar hemoglobin normal umumnya berbeda pada laki-laki dan perempuan. Untuk pria, anmeia biasanya didefinisikan sebagai kadar hemoglobin kurang kurang dari 13, $5 \mathrm{gram} / 100 \mathrm{ml}$ dan pada wanita sebagai hemoglobin kurang dari 12,0 gram/100 ml. (Proverawati, 2011).

Pada kehamilan relatif terjadi anemia karena ibu hamil mengalami hemodelusi (pengenceran) dengan peningkatan volume $30 \%$ sampai $40 \%$ yang puncaknya pada kehamilan 32 sampai 34 minggu. Jumlah peningkatan sel darah $18 \%$ sampai $30 \%$ dan hemoglobin sekitar $19 \%$ (Manuaba, 2010).

Bahaya pada trimester III, anemia dapat menyebabkan terjadinya partus premature, perdarahan ante partum, gangguan pertumbuhan janin dalam rahim, asfiksia intrapartum sampai kematian, gestosisdan mudah terkena infeksi, dan dekompensasi kordis hingga kematian ibu (Mansjoer A. dkk., 2008).

Bahaya anemia pada ibu hamil saat persalinan, dapat menyebabkan gangguan his primer, sekunder, janin lahir dengan anemia, persalinan dengan tindakan-tindakan tinggi karena ibu cepat lelah dan gangguan perjalanan persalinan perlu tindakan operatif (Mansjoer A. dkk., 2008). Anemia kehamilan dapat menyebabkan kelemahan dan kelelahan sehingga akan mempengaruhi ibu saat mengedan untuk melahirkan bayi. (Smith, 2012)

Ibu Hamil memerlukan banyak makanan tambahan diantaranya yaitu protein, vitamin $C$ dan zat-zat besi dibanding wanita biasa. Apabila ibu hamil sampai kekurangan gizi terutama zat besi dan asam folat maka dapat terjadi anemia defisiensi besi karena dalam kehamilan keperluan zat-zat makanan bertambah dan terjadi pula perubahan-perubahan dalam darah dan sum-sum tulang. Selain itu kebutuhan zat gizi selama hamil diperlukan untuk pertumbuhan janin, plasenta dan jaringan lainnya. (Muhilal, 2002)

Masalahnya kebanyakan ibu hamil tidak suka dengan vitamin $C$ yang berbentuk obat. Vitamin $C$ dapat diperoleh dari buah-buahan. Salah satu buah yang mengandung vitamin $C$ dan senyawa bermanfaat untuk kesehatan yaitu tomat. Kandungan tomat dalam 180 gram adalah $24,6 \mathrm{mg}$ vitamin, $0,49 \mathrm{mg}$ zat besi, dan $27 \mathrm{mcg}$ asam folat.
Berdasarkan penelitian Wulandari; Dewi; Afriliana, dan Faraswati (2017) menunjukkan bahwa dari 30 responden, sebanyak 15 responden mengkonsumsi jus strowberry dan 15 responden mengkonsumsi jus tomat. Responden yang mengkonsumsi jus

strowberry tidak ada peningkatan sama sekali terhadap hemoglobin. Responden yang diberikan jus tomat dari 15 responden, sebelum diberikan jus tomat sebanyak 5 responden tidak anemia dan 10 responden anemia ringan, setalah mengkonsumsi jus tomat menjadi 12 responden tidak anemia dan 3 responden anemia ringan. Berdasarkan dua variabel yang diteliti di dapatkan hasil bahwa perbandingan jus strowberry dan jus tomat terhadap peningkatan hemoglobin pada ibu hamil trimester III lebih efektif jus tomat.

Berdasarkan survey pendahuluan yang peneliti lakukan pada januari Tahun 2019 dari hasil observasi pada buku ANC diketahui 48 ibu hamil diantaranya 22 TM III. Sedangkan yang mengalami anemia ringan sebanyak 12 orang dan anemia sedang 8 orang dan 2 orang anemia berat. Alasan peneliti mengambil BPS Rohanah, gedung tataan karena ibu hamil disana belum banyak mengetahui manfaat buah Jus Tomat serta belum pernah dilakukan observasi penyuluhan untuk meningkatkan kadar hb pada ibu hamil juga belum pernah dilakukan penyuluhan penanganan peningkatan kadar hb menggunakan Jus Tomat, sehingga peneliti tertarik untuk melakukan penelitian tentang "Pengaruh Pemberian Jus Tomat terhadap Peningkatan Kadar Hemoglobin pada ibu hamil trimester III"

\section{METODOLOGI PENELITIAN}

Jenis penelitian yang digunakan dalam penelitian ini adalah kuantitatif dengan pendekatan quasi eksperimen dengan rancangan One group pretest - posttest design. Tempat penelitian ini dilaksanakan di BPS Rohanah, STr.Keb. Waktu penelitian dilaksanakan pada bulan Februari - Juli 2019

Populasi dalam penelitian ini adalah Seluruh ibu hamil yang mengalami anemia trimester III di BPS Rohanah, STr.Keb mei 2019 sebanyak 22 ibu hamil dengan jumlah sampel 15 orang.

Pengambilan sample penelitian ini dilakukan dengan menggunakan teknik purposve sampling yaitu mengambil sampel berdasarkan kriteria yang peneliti tentukan. (Notoatmodjo, 2010) 
HASIL DAN PEMBAHASAN

Tabel 1.

Karakteristik Responden

\begin{tabular}{|c|c|c|}
\hline Karakteristik & $\mathrm{n}$ & $\%$ \\
\hline \multicolumn{3}{|l|}{ Usia } \\
\hline - $20-25$ th & 6 & 40.0 \\
\hline - $26-30$ th & 7 & 46.7 \\
\hline - $31-35$ th & 2 & 13.3 \\
\hline \multicolumn{3}{|l|}{ Paritas } \\
\hline - Primipara & 2 & 13.3 \\
\hline - Multipara & 10 & 66.7 \\
\hline - Grandemultipara & 3 & 20.0 \\
\hline \multicolumn{3}{|l|}{ Pendidikan } \\
\hline - SD & 1 & 6.7 \\
\hline - SMP & 5 & 33.3 \\
\hline - SMA & 7 & 46.7 \\
\hline - PT & 2 & 13.3 \\
\hline \multicolumn{3}{|l|}{ Usia Kehamilan } \\
\hline - $\quad 28$ minngu & 3 & 20.0 \\
\hline - $\quad 29$ minggu & 5 & 33.3 \\
\hline - $\quad 30$ minggu & 3 & 20.0 \\
\hline - $\quad 31$ minggu & 4 & 26.7 \\
\hline \multicolumn{3}{|l|}{ Pekerjaan } \\
\hline - Guru & 2 & 13.3 \\
\hline - $\quad I R T$ & 10 & 66.7 \\
\hline - Pedagang & 1 & 6.7 \\
\hline - Tani & 2 & 13.3 \\
\hline
\end{tabular}

Analisa Univariat

Tabel 2.

Rata-Rata Kadar Hb Sebelum Pemberian Jus Tomat

\begin{tabular}{ccccc}
\hline Variabel & $\mathrm{N}$ & Mean & Min-Mak & $\mathrm{SD}$ \\
\hline Sebelum pemberian jus tomat & 15 & 9.687 & $9,1-10,4$ & .4838 \\
\hline
\end{tabular}

Berdasarkan tabel 2 didapatkan bahwa dari 15 responden, rata - rata kadar $\mathrm{Hb}$ sebelum pemberian jus tomat 9.687 dengan nilai minimal 9,1, nilai maksimal 10.4 dab standar deviasi 0.4838 .

Tabel 3.

Rata-Rata Kadar Hb Sesudah Pemberian Jus Tomat

\begin{tabular}{ccccc}
\hline Variabel & $\mathrm{N}$ & Mean & Min-Mak & SD \\
\hline Sesudah pemberian jus tomat & 15 & 11.773 & $10,4-13,8$ & 1.0074 \\
\hline
\end{tabular}

Berdasarkan tabel 3 didapatkan bahwa dari 15 responden, rata - rata kadar $\mathrm{Hb}$ sesudah pemberian jus tomat 11.773 dengan nilai minimal
10.4, nilai maksimal 13.8 dab standar deviasi 1.0074 . 
Analisa Bivariat

Tabel 4.

Pemberian Jus Tomat Terhadap Kadar Hemoglobin

\begin{tabular}{ccccccc}
\hline Variabel & $\begin{array}{c}\text { Mean (Nilai } \\
\text { Rata-Rata) }\end{array}$ & $\begin{array}{c}\text { Selisih } \\
\text { Nilai }\end{array}$ & $\begin{array}{c}\text { SD } \\
\text { (Standar Deviasi) }\end{array}$ & $\mathrm{P}$ (Value) & $\begin{array}{c}\mathrm{N} \\
\text { (Jumlah Sampel) }\end{array}$ & $\begin{array}{c}\mathrm{Cl} 95 \% \\
\text { (low-up) }\end{array}$ \\
\hline $\begin{array}{c}\text { Sebelum pemberian } \\
\text { jus tomat }\end{array}$ & 9.687 & & .4838 & & & $2.62434-$ \\
$\begin{array}{c}\text { Sesudah pemberian } \\
\text { jus tomat }\end{array}$ & 11.773 & 2.08667 & 1.0074 & 0,000 & 15 & 1.54899 \\
\hline
\end{tabular}

Berdasarkan tabel 4 diatas, dapat dilihat nilai rata-rata, standar deviasi dan standar error untuk masing-masing variabel. Nilai rata-rata kadar hemoglobin sebelum pemberian jus tomat adalah 9.687, sedangkan nilai rata-rata kadar hemoglobin sesudah pemberian jus tomat adalah 11.773. Hasil uji statistik yang dilihat dari nilai Sig. (2-tailed) pada tabel dependent sample test adalah 0,000 $<0,05$, maka Ho ditolak. Dapat disimpulkan bahwa ada Pengaruh Pemberian jus tomat Terhadap Peningkatan Kadar $\mathrm{Hb}$ Pada Ibu Hamil.

\section{PEMBAHASAN}

Berdasarkan tabel 4 diatas, dapat dilihat nilai rata-rata, standar deviasi dan standar error untuk masing-masing variabel. Nilai rata-rata kadar hemoglobin sebelum pemberian jus tomat adalah 9.687, sedangkan nilai rata-rata kadar hemoglobin sesudah pemberian jus tomat adalah 11.773. Hasil uji statistik yang dilihat dari nilai Sig. (2-tailed) pada tabel dependent sample test adalah 0,000 <0,05, maka Ho ditolak. Dapat disimpulkan bahwa ada Pengaruh Pemberian jus tomat Terhadap Peningkatan Kadar $\mathrm{Hb}$ Pada Ibu Hamil.

Anemia dalam kehamilan didefinisikan sebagai penurunan kadar hemoglobin kurang dari $11 \mathrm{~g} / \mathrm{dl}$ selama masa kehamilan pada trimester I dan III dan kurang dari $10 \mathrm{~g} / \mathrm{dl}$ selama masa post partum dan trimester II. Darah akan bertambah banyak dalam kehamilan yang lazim disebut hidremia atau hipervolemia. Akan tetapi, bertambahnya sel darah kurang dibandingkan dengan bertambahnya plasma sehingga terjadi pengenceran darah. Perbadingannya tersebut adalah sebagai berikut: plasma $30 \%$, sel darah $18 \%$, dan hemoglobin $19 \%$. Bertambahnya darah dalam kehamilan sudah dimulai sejak kelahiran 10 minggu dan mencapai puncaknya dalam kehamilan antara 32 dan 36 minggu. (Proverawati, 2011)

Kebutuhan zat besi tiap trimester kehamilan berbeda-beda, pada trimester pertama kebutuhan besi justru lebih rendah dari masa sebelum hamil karena wanita hamil tidak mengalami menstruasi dan janin yang dikandung belum membutuhkan banyak besi. Menjelang trimester kedua, kebutuhan zat besi mulai meningkat, pada saat ini terjadi pertambahan jumlah sel-sel darah merah. Pada trimester ketiga, jumlah sel darah merah bertambah mencapai $35 \%$, seiring dengan meningkatnya kebutuhan zat besi sebanyak $450 \mathrm{mg}$. Pertambahan sel darah merah disebabkan oleh meningkatnya kebutuhan oksigen dari janin. Absorpsi besi dapat ditingkatkan oleh kobal, inosin, etionin, vitamin C, HCL, suksinat dan senyawa asam lain. Asam akan mereduksi ion feri menjadi fero dan menghambat terbentuknya kompleks Fe dengan makanan yang tidak larut.

Gizi sangat diperlukan untuk kesehatan ibu, kualitas kehamilan dan keselamatan bayi. Kebutuhan ibu selama kehamilan ialah $800 \mathrm{mg}$ besi, diantaranya $300 \mathrm{mg}$ untuk janin plasenta dan $500 \mathrm{mg}$ untuk pertambahan eritrosit ibu. Dengan demikian ibu membutuhkan tambahan sekitar 2-3 $\mathrm{mg}$ besi/ hari. Ibu Hamil memerlukan banyak makanan tambahan diantaranya yaitu protein, vitamin $\mathrm{C}$ dan zat-zat besi dibanding wanita biasa. Apabila ibu hamil sampai kekurangan gizi terutama zat besi dan asam folat maka dapat terjadi anemia defisiensi besi karena dalam kehamilan keperluan zat-zat makanan bertambah dan terjadi pula perubahan-perubahan dalam darah dan sum-sum tulang. Selain itu kebutuhan zat gizi selama hamil diperlukan untuk pertumbuhan janin, plasenta dan jaringan lainnya. (Muhilal, 2002)

Nutrisi yang baik adalah cara terbaik untuk mencegah terjadinya anemia jika sedang hamil atau mencoba menjadi hamil. Makan makanan yang tinggi kandungan zat besi (seperti sayuran berdaun hijau, daging merah, sereal, telur, dan kacang tanah) dapat membantu memastikan bahwa tubuh menjaga pasokan besi yang diperlukan untuk berfungsi dengan baik. Pemberian vitamin untuk memastikan bahwa tubuh memiliki cukup asam besi dan folat. Pastikan tubuh mendapatkan setidaknya $27 \mathrm{mg}$ zat besi setiap hari. Jika mengalami anemia selama kehamilan, biasanya dapat diobati dengan mengambil suplemen zat besi. Pastikan bahwa wanita hamil dicek pada 
kunjungan pertama kehamilan untuk pemeriksaan anemia. (Proverawati, 2011)

Kebanyakan ibu hamil tidak suka dengan vitamin $C$ yang berbentuk obat. Vitamin $C$ dapat diperoleh dari buah-buahan. Salah satu buah yang mengandung vitamin $C$ dan senyawa bermanfaat untuk kesehatan yaitu tomat. Kandungan tomat dalam 180 gram adalah $24,6 \mathrm{mg}$ vitamin, $0,49 \mathrm{mg}$ zat besi, dan $27 \mathrm{mcg}$ asam folat.

Sebagai sumber vitamin, buah tomat sangat baik untu mencegah dan mengobati berbagai macam penyakit, seperti sariawan karena kekurangan vitamin $\mathrm{C}$, xeropthalmia pada mata karena karena kekurangan vitamin C. Sebagai sumber mineral, buah tomat bermanfaat untuk pembentukan tulang dan gigi. Sedangkan zat besi (fe) yang terkandung dalam buah tomat dapat berfungsi untuk pembentukan sel darah atau hemoglobin. Buah tomat juga mengandung serat yang berfungsi memperlancar proses pencernaan makanan dalam perut, membantu buang kotoran. (Cahyono, 2008)

Berdasarkan penelitian Wulandari; Dewi; Afriliana, dan Faraswati (2017) menunjukkan bahwa dari 30 responden, sebanyak 15 responden mengkonsumsi jus strowberry dan 15 responden mengkonsumsi jus tomat. Responden yang mengkonsumsi jus strowberry tidak ada peningkatan sama sekali terhadap hemoglobin. Responden yang diberikan jus tomat dari 15 responden, sebelum diberikan jus tomat sebanyak 5 responden tidak anemia dan 10 responden anemia ringan, setalah mengkonsumsi jus tomat menjadi 12 responden tidak anemia dan 3 responden anemia ringan. Berdasarkan dua variabel yang diteliti di dapatkan hasil bahwa perbandingan jus strowberry dan jus tomat terhadap peningkatan hemoglobin pada ibu hamil trimester III lebih efektif jus tomat.

Berdasarkan hasil penelitian peneliti berasumsi bahwa ibu hamil setelah mengkonsumsi jus tomatkadar hemoglobin naik nilai rata-rata kadar hemoglobin sebelum pemberian jus tomat adalah 9.627 disebabkan oleh ibu hamil yang sudah mempunyai dua anak dan terjadi kehamilan lagi sehingga kesehatannya akan menurun, sering mengalami kurang darah (anemia) yang merupakan faktor internal yang memengaruhi ibu hamil. sedangkan nilai rata-rata kadar hemoglobin sesudah pemberian jus tomat adalah 12.293 disebabkan karena ibu sering mengkonsumsi makanan yang mengandung nilai gizi bermutu tinggi meskipun tidak berarti makanan yang mahal harganya, ibu hamil teratur mengkonsumsi makanan yang mengandung protein, zat besi, dan minum cukup cairan (menu seimbang). Selain itu faktor tingginya angka kenaikan kadar hemoglobin disebabkan oleh cukupnya waktu untuk beristirahat, kesadaran terhadap asupan gizi yang dikonsumsi sehingga dapat mempercepat kenaikan kadar hemoglobin ibu hamil.

\section{SIMPULAN}

Ada pengaruh pemberian jus tomat terhadap peningkatan kadar $\mathrm{Hb}$ pada ibu hamil.

\section{SARAN}

Bagi ibu hamil dapat mengkonsumsi jus tomat secara rutin guna pencegahan terjadinya anemia serta banyak istirahat istirahat yang cukup.

\section{DAFTAR PUSTAKA}

Ani, L. S. (2013). Buku Saku Anemia Defisiensi Besi: Masa Prahamil dan Hamil. EGC.

Cahyono, J. B. (2008). Membangun budaya keselamatan pasien dalam praktik kedokteran. Yogyakarta: Kanisius.

Kemenkes, R. I. (2013). Riset kesehatan dasar (Riskesdas) 2013. Kemenkes RI. Jakarta.

Kemenkes, R. I. (2016). Pedoman Pencegahan dan Penanggulangan Anemia Pada Remaja Putri dan Wanita Usia Subur (WUS). Direktorat Gizi Masyarakat Direktorat Jenderal Kesehatan Masyarakat Kementerian Kesehatan RI.

Kusmiran, E. (2012). Kesehatan Repsroduksi Remaja Dan WanitaJakarta. Selatan: Salemba Medika.

Manuaba, I. B. G., Manuaba, I. B. G. F., \& Manuaba, I. B. G. (2010). IImu Kebidanan, Penyakit Kandungan dan KB untuk Pendidikan Bidan. Jakarta: EGC, 421-424.

Muhilal, F. J. (2002). Hardinsyah. 1998. Pangan dan Gizi Masa Depan: Meningkatkan Produktivitas dan Daya Saing Bangsa. Prosiding Widyakarya Pangan dan Gizi Nasional VI (hlm. 843-844), 17-20.

Notoatmodjo, S. (2010). Metode penelitian kesehatan, edisi revisi. Jakarta: PT. Asdi Mahasatya.

Proverawati, A. (2011). Anemia dan Anemia kehamilan. Yogyakarta: Nuha Medika, 136-137.

Smith, A. (2012). Events and urban regeneration: The strategic use of events to revitalise cities. Routledge.

World Health Organization. (2015). World health statistics 2015. World Health Organization. 